\title{
Influence of Uneven Secondary Air Supply and Burner Tilt on Flow Pattern, Heat Transfer, and NOx Emissions in a $500 \mathrm{MWe}$ Tangential-Firing Coal Boiler
}

\author{
Hyunbin Jo ${ }^{1}$, Jongkeun Park ${ }^{1}$, Woosuk Kang ${ }^{1}$, Junseok Hong ${ }^{2}$, Sungmin Yoon ${ }^{3}{ }^{\mathbb{D}}$, Howon Ra ${ }^{3}$ \\ and Changkook Ryu ${ }^{1, *}$ (B) \\ 1 School of Mechanical Engineering, Sungkyunkwan University, Suwon 16419, Korea; \\ gusqlsjo@gmail.com (H.J.); pjk890407@skku.edu (J.P.); gigebun2@naver.com (W.K.) \\ 2 R\&D Center, Korea Western Power Co., Ltd., Daejeon 35377, Korea; gaiaforce13@iwest.co.kr \\ 3 Korea Institute of Energy Research (KIER), Daejeon 34129, Korea; ysmable@kier.re.kr (S.Y.); \\ seojun@kier.re.kr (H.R.) \\ * Correspondence: cryu@skku.edu; Tel.: +82-31-299-4841
}

Citation: Jo, H.; Park, J.; Kang, W.; Hong, J.; Yoon, S.; Ra, H.; Ryu, C. Influence of Uneven Secondary Air Supply and Burner Tilt on Flow Pattern, Heat Transfer, and NOx Emissions in a 500 MWe TangentialFiring Coal Boiler. Energies 2021, 14 8352. https://doi.org/10.3390/ en14248352

\section{Academic Editors:}

Giancarlo Sorrentino and

Mejdi Jeguirim

Received: 29 October 2021

Accepted: 9 December 2021

Published: 11 December 2021

Publisher's Note: MDPI stays neutral with regard to jurisdictional claims in published maps and institutional affiliations.

Copyright: (c) 2021 by the authors. Licensee MDPI, Basel, Switzerland. This article is an open access article distributed under the terms and conditions of the Creative Commons Attribution (CC BY) license (https:// creativecommons.org/licenses/by/ $4.0 /)$

\begin{abstract}
Tangential-firing boilers develop large swirling fireballs by using pulverized coal and air from the corners of the burner zone. During operation, however, the boiler may experience an uneven air supply between corners; this deforms the fireball, raising various issues concerning performance and structural safety. This study investigated the characteristic boiler performance and the role of burner tilting in a 500 MWe boiler with secondary air (SA) in two corners that are up to 1.9 times larger than those in the other corners. Computational fluid dynamics simulations with advanced coal combustion sub-models were employed with the following two sets of cases: (i) six cases of actual operation to validate the modeling and (ii) sixteen cases for the parametric study of SA flow ratio and burner tilt between $-15^{\circ}$ and $+26^{\circ}$. The results showed that the uneven SA supply deteriorated the boiler performance in various aspects and the burner tilt can be used to alleviate its impact. With a larger SA supply from the left wind box, the mass flow, heat absorption, and $\mathrm{O}_{2}$ concentration were larger in the right half of the heat exchanger sections owing to the rotating flow. The corresponding imbalance in the reaction stoichiometry increased the peak temperature entering the tube bundles by up to $60{ }^{\circ} \mathrm{C}$ and $\mathrm{NO}$ emissions by $6.7 \%$ as compared with normal operations. The wall heat absorption was up to $19 \%$ larger on the right and front walls. The high burner tilt of $+26^{\circ}$ helped alleviate the impact of uneven SA supply on the heat distribution and uniformity of the flow pattern and temperature, whereas a $+15^{\circ}$ burner tilt was the least favorable.
\end{abstract}

Keywords: coal combustion; tangential-firing; burner tilt; secondary air; NOx emission

\section{Introduction}

Tangential-firing (TF), also known as corner firing, is a boiler configuration commonly adopted for large coal-fired power plants [1]. Both fuel and air distributed in the multilevel burners of a TF boiler are injected from the four corners of a hexahedral furnace with a horizontal bias, forming an imaginary circle at the center. The actual jets of pulverized coal (particle size of $\sim 60 \mu \mathrm{m}$ ) and air create a large rotating flame, often referred to as a fireball, across the burner zone. The TF boiler has the advantages of intensive mixing and long particle residence time for stable combustion and high carbon conversion. The burners can also be tilted for flexible control of the flame height.

Many studies have been reported on the characteristics of pulverized coal furnaces for various operating parameters and their influences on boiler performance, including combustion efficiency, heat absorption, and NOx emission. In particular, computational fluid dynamics (CFD) has been found to be a powerful tool to scrutinize such detailed phenomena. Recent progress in the radiative modeling for gas and particles provided improved accuracy on the prediction of heat transfer in large furnaces [2-6]. 
For pulverized coal boilers, many CFD studies have investigated the tilting and yawing of burners and combustion air [7-13], optimization of air staging [14-16], cofiring [17-19], boiler retrofitting [15,16,20,21]. As regards the burner tilt, Tan et al. [7] evaluated the impact of tilt angles ranging from $0-22^{\circ}$ in a $700 \mathrm{MWe}$ TF boiler. Upward tilting induced stronger turbulence to reduce $\mathrm{CO}$ concentration and increased heat $\mathrm{ab}$ sorption by the superheater $(\mathrm{SH})$ and reheater $(\mathrm{RH})$. However, it increased NOx emission by larger fuel NO formation and lower NO reduction, which were associated with the lower volatile matter concentration, shorter particle residence time, and less reducing atmosphere. Yu et al. [8] coupled CFD with a MATLAB-based thermal hydraulic model for the steam side to alleviate steam tube overheating. It was found that the upward burner tilt of the separated overfire air (SOFA) helped achieve higher boiler efficiency with lower CO and NOx emissions. However, a SOFA tilt angle above $+20^{\circ}$ increased the tube surfaces, exceeding the allowable metal temperature. When operating at a low load (300 MW) in a $630 \mathrm{MW}$ TF boiler [9], an upward burner tilt $\left(+15^{\circ}\right)$ improved the combustion stability, although NOx emission increased. A particular arrangement of the operating burners helped reduce $\mathrm{CO}$ emissions.

The tilting and yawing of the burners and combustion air also influenced the thermal uniformity of the TF boiler. In a study by Tian et al. [10] involving a $700 \mathrm{MWe}$ boiler, the residual swirling flow leaving the burner zone caused deviations in the temperature and velocity in the upper furnace, which led to uneven heat transfer at the final RH. Optimized upward tilting of the burners can effectively reduce deviations. From experiments and CFD simulations, Park et al. [11] identified the yawing of OFA as an effective measure to alleviate the temperature deviation and potential rupture of tubes in the heat exchanger section of 800 MW TF units caused by residual swirl flow. Adding an arch noze below the furnace exit was also helpful in alleviating the gas temperature deviation in a $1000 \mathrm{MW}$ TF boiler [20]. Yao et al. [12] applied the orthogonal statistical method to quantify the influence weights of the tilting and yawing angles of the burners, secondary air (SA), and SOFA for a $660 \mathrm{MW}$ ultra-supercritical boiler. The optimization of the angles reduced the temperature deviation at the furnace exit by as much as $86 \mathrm{~K}$ to $29 \mathrm{~K}$.

The aforementioned studies aim to understand and improve the performance of TF boilers under normal operating conditions. However, actual systems may suffer from various problems while the operation needs to continue until scheduled maintenance. One of the abnormal operating conditions is the uneven air distribution between the four corners. The combustion air of the TF furnace was supplied through preheaters and split into left and right windboxes using a forced draft fan. During normal operation, the rotating flames of the fireball in the TF boiler can alleviate minor disturbances in the airflow distribution. However, when air preheaters are contaminated, the axisymmetry of the airflow between corners can be significantly broken and gradually worsen as the operation continues. The uneven air distribution deforms the fireball and causes large deviations in the local gas velocity, reaction atmosphere, temperature, and heat transfer, which deteriorates the boiler performance and may lead to severe damage to the boiler. An analysis of the combustion performance in such abnormal conditions can be helpful in understanding the capability of the TF boiler and improving the operation control; however, studies focusing on this issue have not been reported in the literature.

This study investigated the impact of uneven airflow distribution between corner burners occurring in a 500 MWe tangential-firing boiler caused by air preheater contamination. Six actual operation cases were selected in which the airflow ratio between corners ranged from 1.0 to 1.91 at different burner tilt angles. CFD simulations were performed for the six cases to validate the modeling approach using the measured data. Subsequently, a new set of cases was established for CFD simulations to isolate the influence of uneven air supply and burner tilt from other operational variables such as coal properties and boiler load. The results were discussed in terms of the boiler performance with a detailed analysis of the flow and temperature uniformity, furnace exit gas temperature (FEGT), coal combustion, heat transfer, and NOx emissions. 


\section{Numerical Methods}

\subsection{Target Boiler}

Figure 1a shows the coal-fired boiler investigated in this study, which adopted the TF configuration at a capacity of 500 MWe. This is one of 20 identical units in Korea, and has been suffering from the problem of uneven SA supply described. The boiler consisted of a burner zone in the lower furnace incorporating six levels of coal burner and closecoupled overfire air (CCOFA) at four corners and a series of convective tube bundles in the upper furnace. The coal burners including various SA ports and CCOFA were horizontally biased from the furnace center such that the jets of coal and air created a fireball across the burner zone.

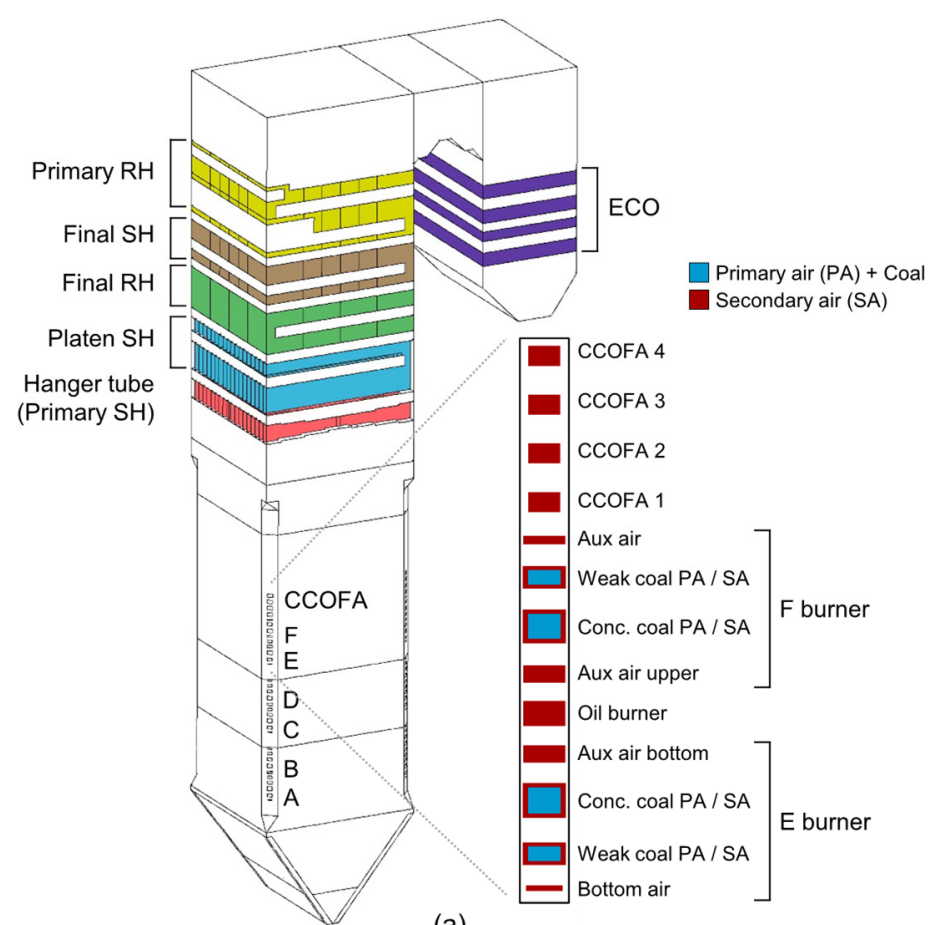

(a)

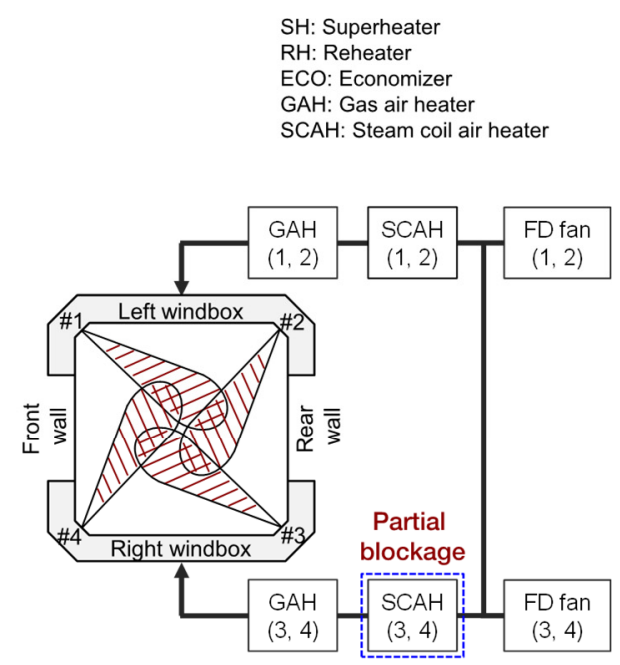

(b)

Figure 1. Schematic of (a) $500 \mathrm{MW}$ tangential-firing boiler and (b) secondary air (SA) supply system.

Figure $1 \mathrm{~b}$ illustrates the SA supply system for the burner SA and CCOFA. While primary air (PA) was sent into six coal mills to transport pulverized coal, SA was supplied through two streams consisting of a forced draft fan, a steam coil air heater (SCAH), and a gas air heater. Each stream of the SA supply system covered two corners: the left windbox for \#1 and \#2 corners and the right windbox for \#3 and \#4 corners. The SA was preheated by the heaters and then split into various ports around the coal burners and CCOFA, as illustrated in Figure 1a. Ideally, the two SA streams should have identical flow rates. However, addition of a small volume of off-gas from the biomass drying process containing fine particles into the right $\mathrm{SCAH}$ gradually contaminated the air passage and reduced the SA flow rate to corners \#3 and \#4. This problem worsened as the operation continued; therefore, the load had to be reduced. The uneven SA distribution between corners broke the axisymmetry of the fireball and influenced the performance of the boiler, which was investigated in this study with actual and simulated operating cases.

The arrangement of the heat exchangers is illustrated in Figure 2. The hanger tube has four sections, of which the steam is connected to a platen SH. The tube sections are switched between the left and right, and the inner and outer sections are switched to the final SH. The primary and final RHs also exhibited the same arrangement. 
(L: left, R: Right, O: outer, I: Inner)

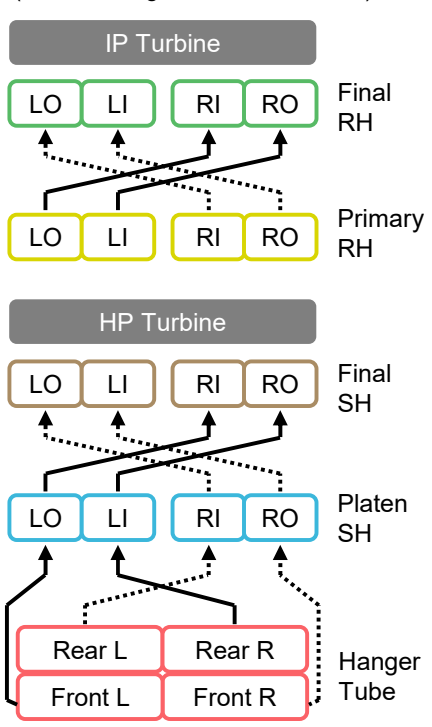

Figure 2. Arrangement of heat exchanger sections for superheaters and reheaters.

\subsection{Actual Operation Cases}

From the field survey, five cases with different degrees of uneven SA supply were selected from the operation records between January and May 2020, together with one normal operation before this issue in 2016. Then, the detailed operating conditions were retrieved and averaged for $1 \mathrm{~h}$ from the recorded data stored for every minute, which included the coal throughput, air flow rates and temperatures for PA and SA, burner tilt angle, measured $\mathrm{O}_{2}$ and $\mathrm{NOx}$ concentrations at the economizer exit, and heat absorption (the steam flow rate, temperature, and pressure for each heat exchanger). The coal properties were also acquired from the data, which were analyzed on a daily basis. Detailed information on the operating conditions and coal properties are presented in Tables S1 and S2 of the Supplementary Information, respectively.

Table 1 presents the cases with different $S A$ ratios, selected from the operation records of the boiler. The SA ratio was defined as the ratio of the SA flow rate (burner SA and CCOFA) for the left windbox (\#1 and \#2 corners) divided by that from the right windbox (\#3 and \#4 corners). Case A1 represented a normal operation with an almost equal distribution of SA supply between the corners. Cases A2 to A4 had an SA ratio of approximately 1.35 but with different burner tilts of downward $\left(-15^{\circ}\right)$, horizontal $\left(1^{\circ}\right)$, and upward $\left(26^{\circ}\right)$, respectively. The SA ratio increased to 1.71 in case A5 and further to 1.93 in case A6. Owing to the uneven SA distribution, the boiler load had to be reduced to a turbine output of approximately $360 \mathrm{MWe}$ in these two cases together with a high tilt angle $\left(26^{\circ}\right)$ to meet the target steam temperature at the reheater exit. Because the cases were selected from the operation data, input parameters such as the thermal input, coal properties, and burner tilt angle were not identical. The total airflow rate corresponded to an overall stoichiometric ratio of 1.14-1.21 (i.e., excess air ratio of 14-21\%). It was determined from the measured $\mathrm{O}_{2}$ concentration at the boiler exit, coal properties, and coal throughput. Then, the total SA flow rate was calculated by difference from the measured PA flow rate. For the coal properties measured on a daily basis, direct use of the measured value for SA caused some discrepancy in the $\mathrm{O}_{2}$ concentration. Because the combustion characteristics including $\mathrm{NO}$ emission are sensitive to the excess air ratio, the SA flow rate was adjusted to match the measured $\mathrm{O}_{2}$ concentration while keeping the SA ratio identical to the measured data. Furthermore, the flow rate of the CCOFA was not measured separately in the plant. Therefore, the stoichiometric ratio in the burner zone was assumed to be 0.97 , and the remainder was for CCOFA. 
Table 1. Summary of actual operating conditions during uneven SA supply between corners.

\begin{tabular}{|c|c|c|c|c|c|c|c|}
\hline & & A1 & A2 & A3 & A4 & A5 & A6 \\
\hline \multicolumn{2}{|c|}{ SA Ratio between Corners, $(\# 1+\# 2) /(\# 3+\# 4)$} & 1 & 1.39 & 1.36 & 1.33 & 1.71 & 1.93 \\
\hline \multicolumn{2}{|c|}{ Turbine Output [MWe] } & 487 & 460 & 459 & 460 & 357 & 365 \\
\hline \multicolumn{2}{|c|}{ Burner Tilt Angle $\left[{ }^{\circ}\right]$} & -2 & -15 & 1 & 26 & 26 & 26 \\
\hline Stoichiometric & Overall & 1.14 & 1.15 & 1.15 & 1.15 & 1.21 & 1.21 \\
\hline Ratio & Burner Zone & 0.97 & 0.97 & 0.97 & 0.97 & 0.97 & 0.97 \\
\hline
\end{tabular}

\subsection{Simulated Cases for Parametric Study}

Because the actual operation cases have different coal properties, excess air ratios, and boiler loads, it was difficult to analyze the simulation results of actual operating cases with respect to the magnitude of uneven SA distribution and burner tilt. Therefore, a new set of simulation cases was established for the parametric study, whereas actual operation cases were used to validate the CFD modeling. For 16 cases, as summarized in Table 2, the SA ratio was varied from 1.0 to 1.9 , and the burner tilt from $-15^{\circ}$ to $+26^{\circ}$, based on the range of these parameters in the actual operation cases. Other operating conditions, such as the coal properties, excess air ratio, and boiler load, were fixed to those of case A2, in which the CFD results were in good agreement with the measured data. Each simulation case was named after the SA ratio and burner tilt angle. For example, case $\mathrm{C} 1.7+15^{\circ}$ refers to a case with an SA ratio of 1.7 and a tilt angle of $+15^{\circ}$.

Table 2. Simulation cases for parametric studies of uneven SA distribution and burner tilting.

\begin{tabular}{|c|c|c|}
\hline \multicolumn{2}{|c|}{ Parameter } & Values \\
\hline \multicolumn{2}{|c|}{ SA Ratio Between Corners, $(\# 1+\# 2) /(\# 3+\# 4)$} & $1.0,1.3,1.7,1.9$ \\
\hline Burner Tilt Angle & & $-15^{\circ}, 0^{\circ},+15^{\circ},+26^{\circ}$ \\
\hline $\begin{array}{l}\text { Fixed } \\
\text { (Based on Case A2) }\end{array}$ & $\begin{array}{l}\text { Coal Properties } \\
\text { Coal Throughput } \\
\text { Stoichiometric Ratio } \\
\text { Air Supply }\end{array}$ & $\begin{array}{l}\text { Total moisture 15.5, Ash } 9.3 \text { wt.\%wet, } \\
\text { C } 74.5, \mathrm{H} 4.3, \mathrm{O} 8.9, \mathrm{~N} 1.8, \mathrm{~S} 0.4 \mathrm{wt} . \% \text { daf, } \\
\text { HHV } 5932 \mathrm{kcal} / \mathrm{kg} \\
50.4 \mathrm{~kg} / \mathrm{s} \\
\text { Overall 1.15, Burner zone } 0.97 \\
\text { PA } 98.0 \mathrm{~kg} / \mathrm{s}\left(62.3^{\circ} \mathrm{C}\right), \text { SA } 386.8 \mathrm{~kg} / \mathrm{s}\left(294.2^{\circ} \mathrm{C}\right)\end{array}$ \\
\hline
\end{tabular}

\subsection{Numerical Methods}

In the CFD simulations, a mesh was constructed for the boiler using 4,757,476 cells $(4,445,838$ hexahedral and 311,638 tetrahedral cells), as shown in Figure S1 of the Supplementary Information. The mesh sensitivity was evaluated in our previous study [22], which was shown to have minor deviations in key results (carbon conversion, $0.12 \%$; exit NO concentration, $1.9 \%$; wall heat absorption, $0.2 \%$ ) as compared to a finer mesh. The mesh used in this study for the heat exchanger section was improved from the previous version to address more detailed shapes.

The modeling methods and solution strategy were also based on our previous study [22]. The conservation equations of mass, momentum, energy, and chemical species were solved using Ansys Fluent version 17.2 [23] with built-in and user-defined submodels for reactions, turbulence, and heat transfer. The pressure-velocity coupling was modeled using the PRESTO! algorithm with the quadratic upstream interpolation for convective kinematics (QUICK) scheme for spatial discretization of the governing equations [23]. The turbulence was solved using the realizable $\mathrm{k}-\varepsilon$ model, which was modified from the standard $\mathrm{k}-\varepsilon$ model to improve the accuracy of the swirling flow [24]. The discrete ordinates model [25] was employed for radiation, which solved the radiative transfer equation with an angular discretization of 5 in both the polar and azimuthal directions and 3 in their subpixels. Compared to P1 model, the discrete ordinate model is applicable to all optical thicknesses 
and can better account for particle radiation [6], providing better accuracy [26,27]. Gas absorption was considered using the weighted sum of the gray gases model proposed by Yin et al. [5] employed using a user-defined function. This model can better resolve the influence of the variations in $\mathrm{CO}_{2}$ and $\mathrm{H}_{2} \mathrm{O}$ concentrations for a wider range of temperature and mean beam length compared to Smith et al.'s model [28]. The pulverized coal particles were considered using the discrete phase method, which repeatedly calculates the trajectories of individual particles in the Lagrangian scheme, updating their heat and mass interactions with the gas phase. The coal was represented by 49,560 particles with 10 diameters ranging from 5.9 to $204 \mu \mathrm{m}$ at an average of $50 \mu \mathrm{m}$.

Table 3 summarizes the reaction submodels for coal combustion, gaseous reactions, and NOx emissions. The kinetics and yields of devolatilization for individual coals (Table S2) were determined using Flashchain of PCCoalLab, which is an advanced coal network model [29]. A user-defined function was used to enable multiple volatile products (tar, $\mathrm{CO}, \mathrm{CO}_{2}, \mathrm{H}_{2} \mathrm{O}, \mathrm{H}_{2}, \mathrm{CH}_{4}$, and $\mathrm{C}_{\mathrm{x}} \mathrm{H}_{\mathrm{y}}$ ) from the model because the built-in model allows only a single gas species. The details of the devolatilization kinetics and product yields are presented in Table S3 of the supplementary information, including those for the six actual operation cases. The char conversion by $\mathrm{O}_{2}, \mathrm{CO}_{2}$, and $\mathrm{H}_{2} \mathrm{O}$ was predicted using the unreacted core shrinking model [30] based on another user-defined function. The unreacted core shrinking model considers the competing rates between the surface kinetic $\left(\mathrm{k}_{\mathrm{s}}\right)$, boundary diffusion $\left(\mathrm{k}_{\text {diff }}\right)$, and the resistance of the ash layer $\left(\mathrm{k}_{\text {dash }}\right)$, which is appropriate for the high-temperature atmosphere in a large-scale furnace. The gaseous reactions were established using the global reaction scheme based on Jones and Lindstedt [31] for hydrocarbons and Smith and Smoot [32] for tar. The finite-rate/eddy-dissipation model of Magnussen and Hjertager [33] was used to consider the turbulence-chemistry interaction.

Table 3. Summary of reaction submodels employed for computational fluid dynamics (CFD) simulation.

\begin{tabular}{|c|c|}
\hline Category & Submodels \\
\hline Coal Combustion & 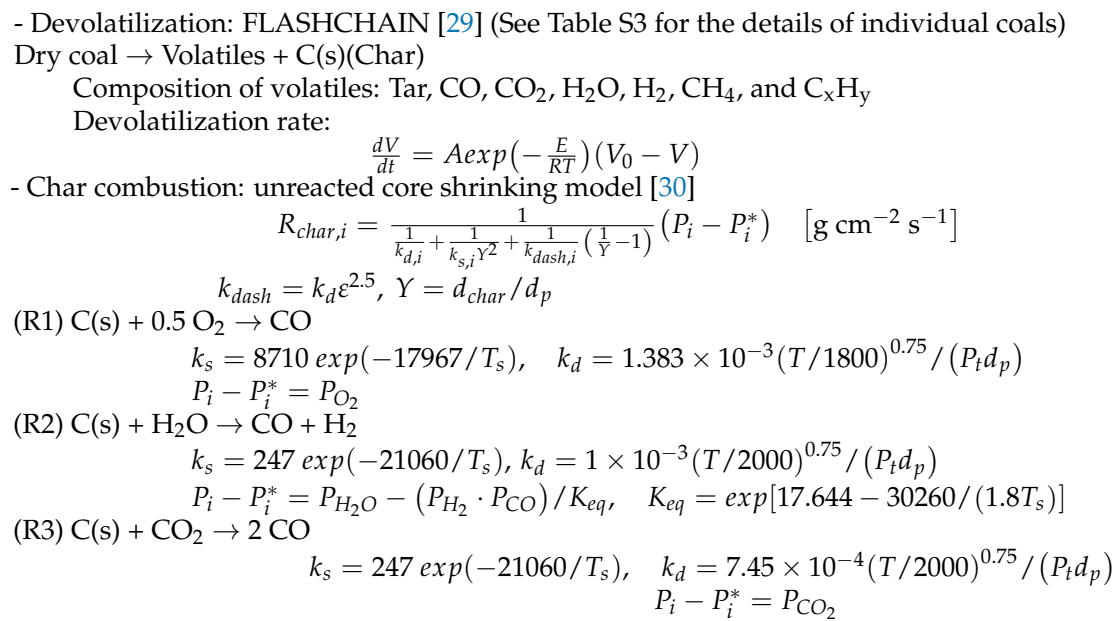 \\
\hline $\begin{array}{c}\text { Species, } \\
\text { Gas Reaction }\end{array}$ & 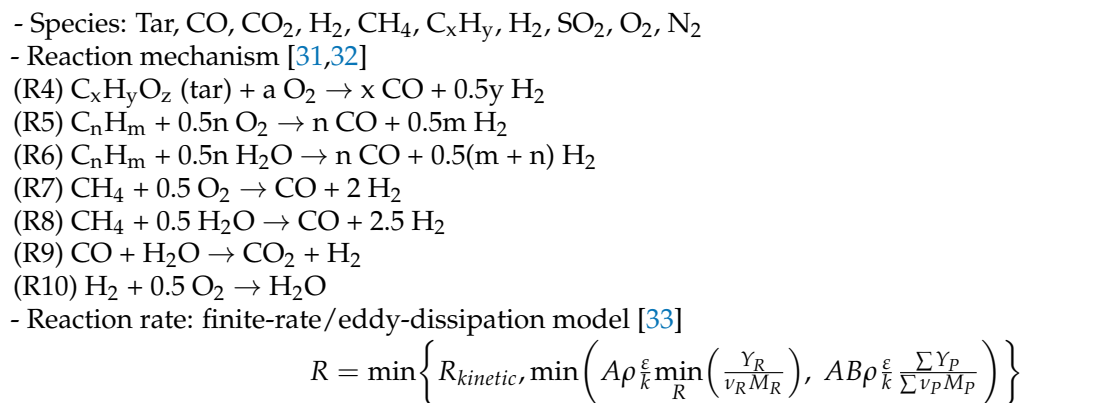 \\
\hline
\end{tabular}


Table 3. Cont.

\begin{tabular}{cl}
\hline Category & \multicolumn{1}{c}{ Submodels } \\
\hline \multirow{3}{*}{ Discrete Phase } & - Lagrangian scheme with stochastic tracking for turbulence \\
& - Number of particles: 49,560 \\
& - Particle size: $5.88-204 \mu \mathrm{m}$ \\
\hline \multirow{2}{*}{ NOx } & - Thermal NOx: Extended Zeldovich mechanism [34] \\
& - Fuel NOx: De Soete [35] \\
& - Volatile-N intermediates: $\mathrm{HCN} 83.33 \%, \mathrm{NH}_{3} 16.67 \%$ \\
\hline
\end{tabular}

In the NO reactions, the thermal NO was solved for the extended Zeldovich mechanism with rate constants taken from Hanson and Salimian [34]. The fuel NOx mechanism [35] considered the partitioning of fuel-N into volatile- $\mathrm{N}$ released as $\mathrm{HCN}$ 5: $\mathrm{NH}_{3} 1$ and into char-N released as NO. The proportions of volatile and char-N were determined using Flashchain. The reduction of $\mathrm{NO}$ to $\mathrm{N}_{2}$ by active carbons on the char surface was considered to have a Brunauer-Emmett-Teller surface area of $150 \mathrm{~m}^{2} / \mathrm{g}$.

In the boundary conditions, the steam temperature of each heat exchanger was determined from the average of the inlet and outlet values, and detailed heat transfer conditions were tuned to match the operation data of case A1. The furnace wall (evaporator) had an overall heat transfer coefficient of $250 \mathrm{~W} / \mathrm{m}^{2} \mathrm{~K}$ [36] and a wall emissivity of 0.7 . The hanger tube (primary $\mathrm{SH}$ ) and platen $\mathrm{SH}$ were modeled as flat walls, whereas the tube bundles from the final $\mathrm{SH}$ to the economizer were simplified to have local source terms for directional flow resistances, convection, and radiation based on the detailed tube geometry [37]. The heat transfer coefficient of each heat exchanger was tuned for Case A1 and then applied to other cases with the respective average steam temperatures.

\section{Results and Discussion}

\subsection{Validation of Computational Fluid Dynamics (CFD) Simulations for Actual Operation Cases}

Table 4 compares the measured and predicted $\mathrm{O}_{2}$ concentrations on the left and right halves at the economizer exit for actual operation cases with an SA ratio of up to 1.91 with different burner tilts and loads. The measured values were averaged from the three sensors in each half. Case A1 had a $0.26 \%$ higher $\mathrm{O}_{2}$ concentration in the measured data for the right half, whereas the CFD results had almost equal values. This implies some uncertainties in the operation conditions, such as the flow rate of coal between corners and slagging/fouling in tube bundles. In particular, unusually large deposits of ash partially blocking the gas passages were found in the tube bundles including the platen SH during maintenance. This could have significantly influenced the flow pattern in the upper furnace. With the cases of uneven SA distribution, the right half had $0.33 \%$ to $0.69 \%$ higher $\mathrm{O}_{2}$ concentrations in the measured data, except for case A4. The CFD results were consistent; however, the difference was increased from 0.72 to $1.46 \%$. The overestimation of the differences in the $\mathrm{O}_{2}$ concentrations could result from the physical mixing enhanced by tube bundles, which were not considered in the CFD analysis.

Table 4. Comparison of measured and predicted $\mathrm{O}_{2}$ and $\mathrm{NOx}$ concentrations at the economizer exit.

\begin{tabular}{|c|c|c|c|c|c|c|c|c|}
\hline & Case & & A1 & A2 & A3 & A4 & A5 & A6 \\
\hline \multirow{6}{*}{$\mathrm{O}_{2}$ (\%dry) } & \multirow{3}{*}{ Measured } & Left & 2.48 & 2.49 & 2.6 & 3.03 & 3.51 & 3.49 \\
\hline & & Right & 2.74 & 3.18 & 2.97 & 2.51 & 3.92 & 3.82 \\
\hline & & Average & 2.61 & 2.83 & 2.79 & 2.77 & 3.71 & 3.66 \\
\hline & \multirow{3}{*}{ Predicted } & Left & 2.68 & 2.49 & 1.98 & 2.28 & 2.89 & 2.93 \\
\hline & & Right & 2.67 & 3.21 & 3.64 & 3.29 & 4.58 & 4.39 \\
\hline & & Average & 2.67 & 2.85 & 2.81 & 2.79 & 3.73 & 3.66 \\
\hline \multirow{2}{*}{$\begin{array}{l}\mathrm{NOx} \\
\left(\mathrm{ppm}, 6 \% \mathrm{O}_{2}\right)\end{array}$} & Measured & & 153 & 190 & 223 & 165 & 100 & 98 \\
\hline & Predicted & & 111 & 194 & 188 & 147 & 97 & 109 \\
\hline
\end{tabular}


Table 4 also compares the average NOx concentrations (corrected to $6 \% \mathrm{O}_{2}$ ) at the economizer exit. Generally, the trend in the predicted NOx concentrations was in good agreement with the measured data, despite the large variations in the operating conditions. Although the CFD modeling provided the detailed contribution of the thermal and fuel NOx mechanisms, the NOx emissions resulted from complicated interactions between fuel properties (fuel-N content, partitioning into volatile-N and char-N, char and ash contents) and operating parameters (thermal input, SA ratio, and burner tilt), which varied widely between cases. This made it difficult to isolate and conclude the influence of the SA ratio and burner tilt. Therefore, further analysis is presented in the next section for the new set of simulation cases (Table 2) based on case A2.

Figure 3 shows a comparison of the measured and predicted heat absorptions in the heat exchangers. Generally, the heat absorption trends were in fairly good agreement between the measured and predicted results, which implies that the gas temperature distribution would also be reasonable. In cases A5 and A6 with a low load of approximately $360 \mathrm{MWe}$, the heat absorption on the wall was slightly over-predicted. This could be because Case A1 was taken from an early date of operation after the maintenance clearing the wall, whereas the two cases were from later dates before a new maintenance that could have a significant accumulation of ash slagging. The trends in cases A2-A4 exhibited the influence of burner tilt well $\left(-15^{\circ},+1^{\circ}\right.$, and $+26^{\circ}$, respectively), in which the upward tilting reduced the heat absorption on the wall while increasing that in the convective sections. This is further analyzed in the next section with new cases of the parametric study.

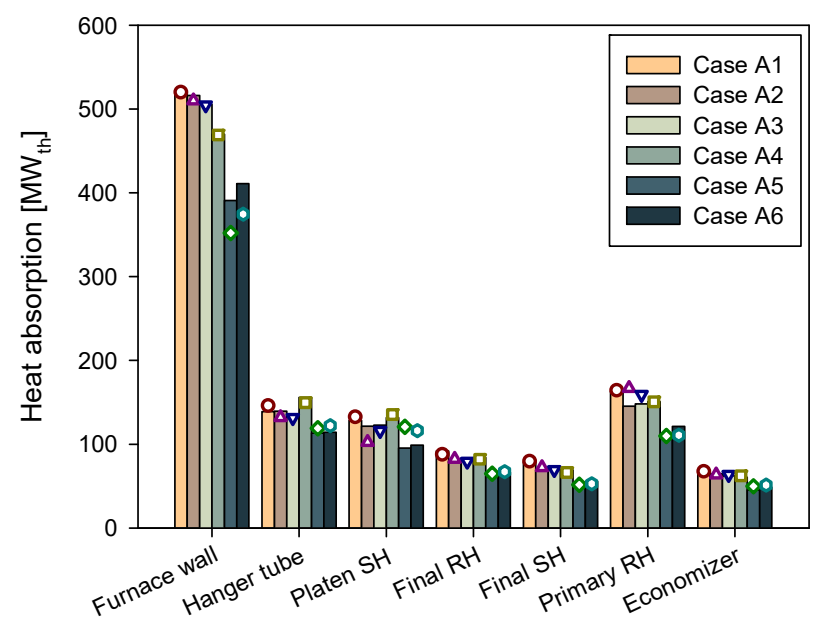

Figure 3. Comparison of measured (symbols) and predicted heat absorption in heat exchangers.

\subsection{Parametric Study: Influence on Flow Pattern and Temperature Distribution}

Figure 4 compares the flow pattern of selected cases among the cases in Table 2 for the parametric study, varying only the SA ratio and burner tilt. Case $\mathrm{C} 1.0+0^{\circ}$ is the reference case, which has an equal airflow distribution between the four corners, resulting in a clockwise swirling flow (fireball) at the center across the burner zone. The swirling flow then expanded toward the walls above the CCOFA by centrifugal force. This led to the formation of a large circulating flow at the center across the heat exchangers, which was identified as a blue oval shape on the platen SH level in Figure 4. When the SA supply from the left windbox to corners \#1 and \#2 was 1.7 times stronger, the center of the fireball was pushed toward the front wall, as shown in the subset of Figure 4 for case $1.7+0^{\circ}$, whereas the slow circulating flow appearing in the platen $\mathrm{SH}$ level was moved toward the left wall. The flow patterns remained similar for burner tilting of $0^{\circ}$ and $+15^{\circ}$. When the burner tilt increased to $+26^{\circ}$ (case $\left(1.7+26^{\circ}\right.$ ), the jets from corners \#1 and \#2 flowed sharply upward along the rear and right walls such that the fireball was severely deformed. It also led to two high-speed regions on the platen SH level close to the walls near corners \#2 and \#3, respectively, whereas a weak circulating flow appeared close to the center. 


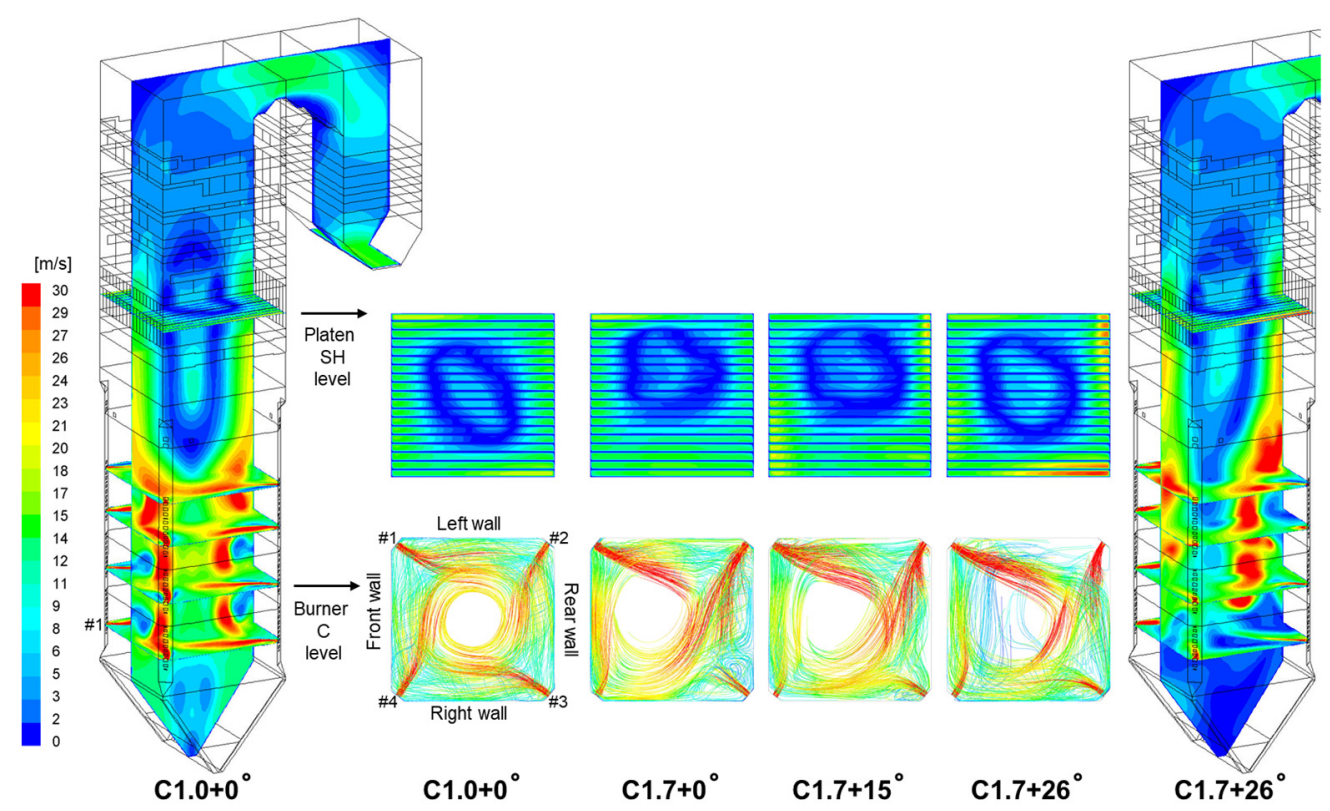

Figure 4. Predicted contours of velocity magnitude and pathlines for cases $\mathrm{C} 1.0+0^{\circ}, \mathrm{C} 1.7+0^{\circ}, \mathrm{C} 1.7+15^{\circ}$, and $\mathrm{C} 1.7+26^{\circ}$.

Figure 5 shows the predicted temperature distributions for the selected cases. A high-temperature region developed in the upper burner zone with a peak temperature of $1611^{\circ} \mathrm{C}$ for case $\mathrm{C} 1.0+0^{\circ}$. The temperature rapidly dropped in the convective sections, in which the value was relatively higher in the near-wall area with larger gas flow rates. The low-temperature region at the center of the FEGT and platen SH levels coincided with the weak circulating flow in Figure 3. With the uneven SA supply of cases C1.7, the axisymmetry of the temperature pattern collapsed in the burner zone, as shown in the two cross-sections of burner A and C levels. At the FEGT level ( $1.5 \mathrm{~m}$ below the hanger tube), a high-temperature region above $1310{ }^{\circ} \mathrm{C}$ was identified near the front and right walls. This was because the uneven SA supply with even coal supply between corners caused an imbalance in the reaction stoichiometry, which delayed the reactions of the more fuel-rich region to the upper furnace.
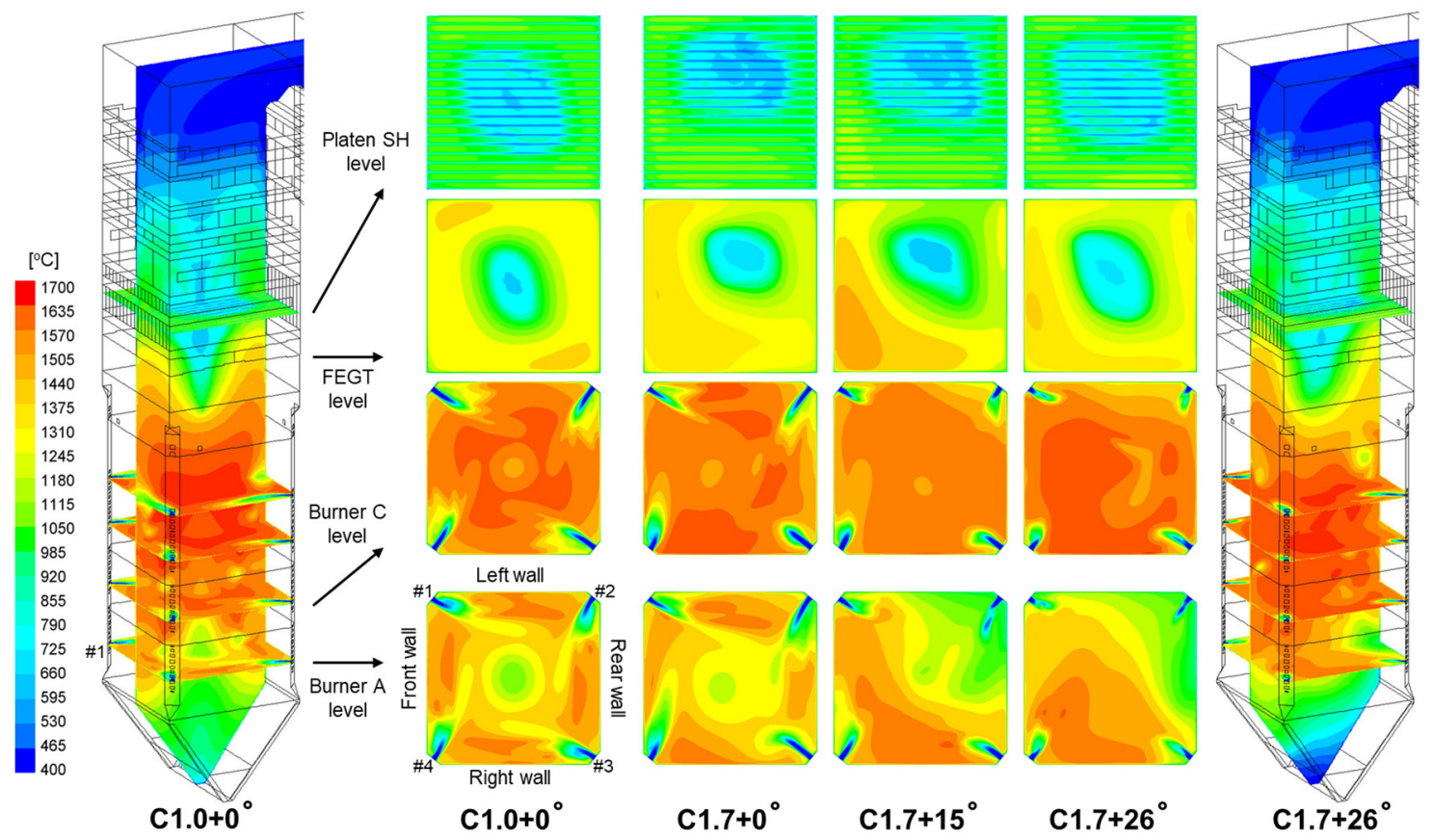

Figure 5. Predicted contours of gas temperature for cases $\mathrm{C} 1.0+0^{\circ}, \mathrm{C} 1.7+0^{\circ}, \mathrm{C} 1.7+15^{\circ}$, and $\mathrm{C} 1.7+26^{\circ}$. 
The magnitude of non-uniformity in the flow across the boiler was evaluated quantitatively, by calculating the deviations in the z-velocity and temperature between the pairs of axisymmetric points on key horizontal cross-sections, as shown in Figure 6. The subset contour in Figure 6a illustrates two pairs of axisymmetric points with respect to the furnace center. The difference between pairs was averaged using area-weighting. Case $\mathrm{C} 1.0+0^{\circ}$ (Figure 6a) exhibited tiny deviations, indicating that the flow maintained axisymmetry. The deviations slightly increased on the primary $\mathrm{RH}$, in which the axisymmetry was forced to break by the shape of the tube bundles, especially for temperature. With an uneven SA supply, the deviations in the z-velocity and temperature increased drastically, as shown in Figure $6 \mathrm{~b}-\mathrm{d}$. The differences were the largest on the hanger tube where all SAs were injected and then decreased gradually according to the resistance of the heat exchangers. The maximum deviation was observed in case $\mathrm{C} 1.7+15^{\circ}$ with $128.6^{\circ} \mathrm{C}$ on the hanger tube level and $4.37 \mathrm{~m} / \mathrm{s}$ on the burner A level. These represented $11.89 \%$ of the average temperature and $79.6 \%$ of the average z-velocity on the respective cross-sections. One interesting result was that the differences in both the z-velocity and temperature were significantly lowered at the highest burner tilt, especially in the heat exchanger sections, for case $\mathrm{C} 1.7+26^{\circ}$, as shown in Figure 6d. This was consistent with the contours of Figures 4 and 5, in which the cold circulation zone appeared at the center of the platen $\mathrm{SH}$ level and above, unlike in other burner tilt angles.

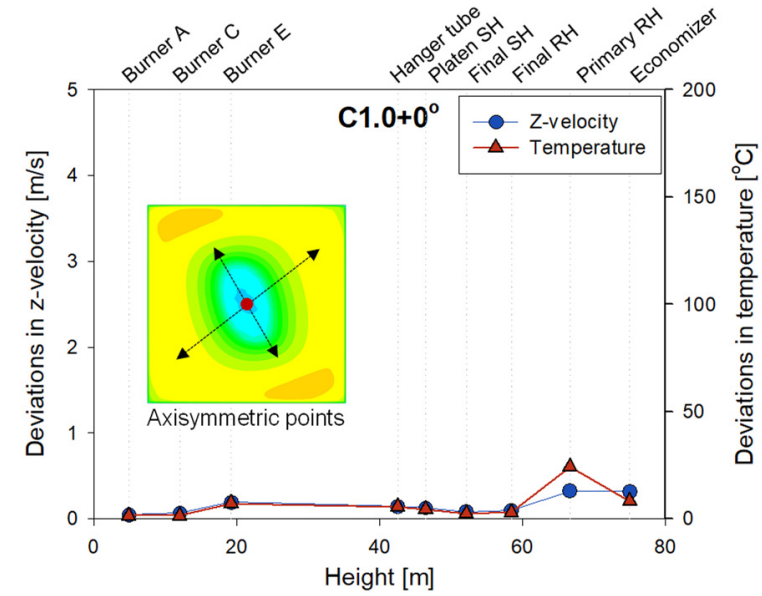

(a)

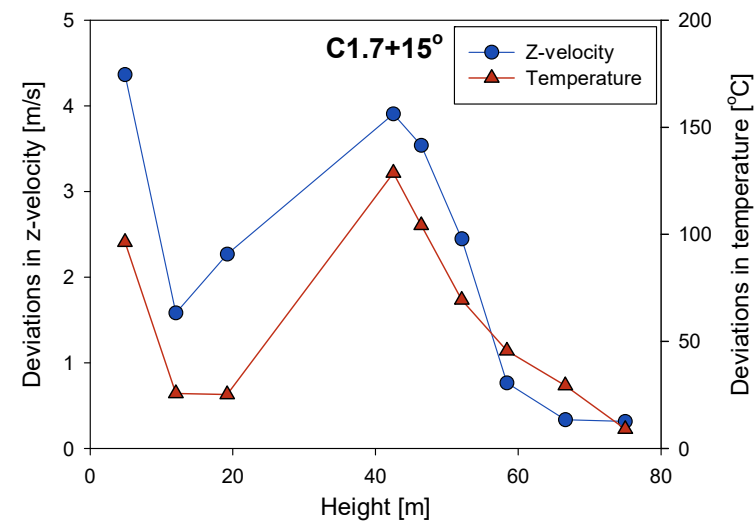

(c)

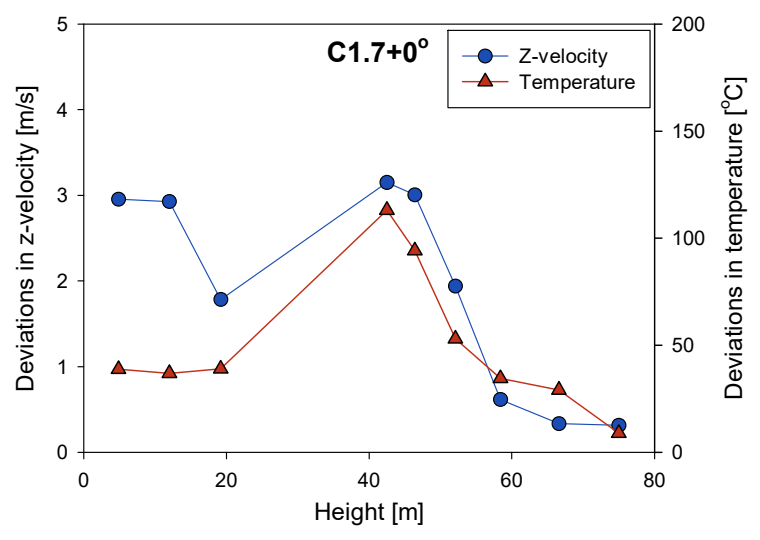

(b)

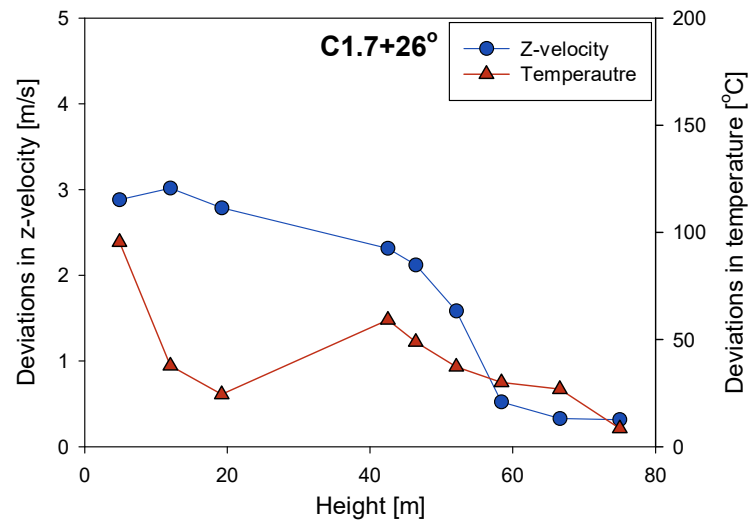

(d)

Figure 6. Deviations in z-velocity and temperature between axisymmetric points around the center of the furnace on horizontal cross-sections for $(\mathbf{a}) \mathrm{C} 1.0+0^{\circ}$, (b) $\mathrm{C} 1.7+0^{\circ}$, (c) $\mathrm{C} 1.7+15^{\circ}$ and (d) $\mathrm{C} 1.7+15^{\circ}$.

The deviations between the axisymmetric points were summarized into a single value for each case with respect to the average values of the key cross-sections. As shown in Figure $7 \mathrm{a}$, the non-uniformity in the mass flow (i.e., z-velocity) was approximately $20 \%$ 
with an SA ratio of 1.3, and the increase slowed down with a larger SA ratio. Although the trend was similar between cases, the deviations in temperature (Figure $7 \mathrm{~b}$ ) were much smaller, with a maximum of $6.23 \%$ in case $\mathrm{C} 1.9-15^{\circ}$. This is because the temperature was influenced by chemical reactions and was distributed through radiation. Generally, the non-uniformity was the largest at a tilt angle of $+15^{\circ}$ and decreased significantly at $+26^{\circ}$.

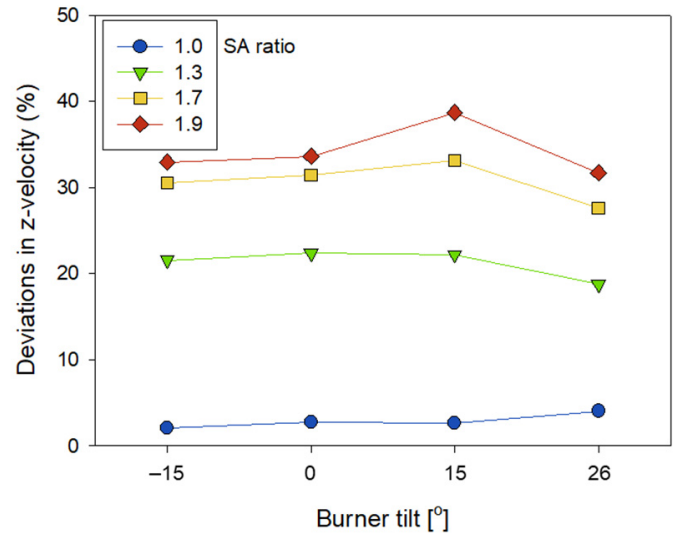

(a)

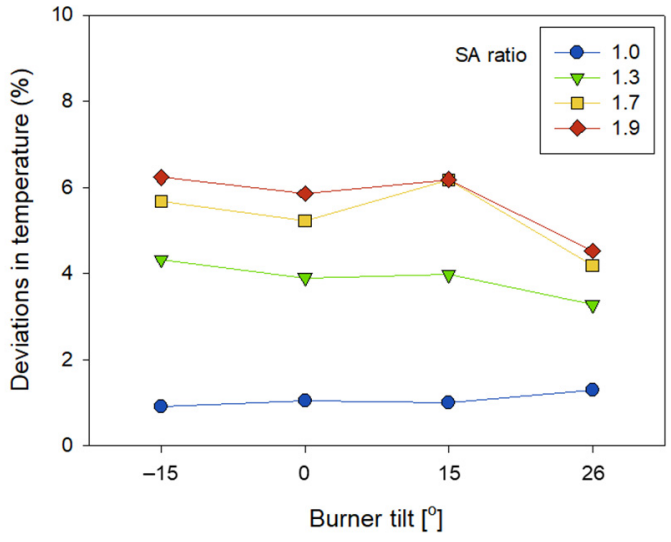

(b)

Figure 7. Relative deviations between axisymmetric points in (a) z-velocity and (b) temperature averaged for key horizontal cross-sections.

The aforementioned non-uniformity in the flow and temperature can lead to operational issues such as excessive surface temperature, slagging, and erosion. The peak temperature at the FEGT level $\left(\mathrm{T}_{\text {peak }}\right)$ is of particular interest with regard to the stickiness of ash leading to slagging on the heat exchanger surfaces. $T_{\text {peak }}$ is shown in Figure 8 for all cases of the parametric study. During normal operations ( $\mathrm{C} 1$ cases), $\mathrm{T}_{\text {peak }}$ increased by tilting the burners upward, which is consistent with previous studies $[8,9,12,38]$. With the uneven SA supply, $\mathrm{T}_{\text {peak }}$ increased by $16.4-60.0^{\circ} \mathrm{C}$ as compared with the respective normal operation cases with identical burner tilt. In particular, a burner tilt of $+15^{\circ}$ was found to be the worst in terms of the slagging propensity. At a burner tilt of $+26^{\circ}$, however, $\mathrm{T}_{\text {peak }}$ decreased for the cases of uneven SA supply. This was also identified in the subset of Figure 5 for case $\mathrm{C} 1.7+26^{\circ}$. $\mathrm{T}_{\text {peak }}$ appearing on the front wall, in this case, was in a fuel-rich pocket with a lower gas velocity than that in case $\mathrm{C} 1.7+15^{\circ}$. The gas stream through the peak temperature zone experienced a larger temperature drop owing to heat loss to the wall because the gas flowed closer to the wall by the highest burner tilt. The lower $\mathrm{T}_{\text {peak }}$ in case $\mathrm{C} 1.7+26^{\circ}$ was consistent with the temperature deviation results shown in Figure $7 \mathrm{~b}$.

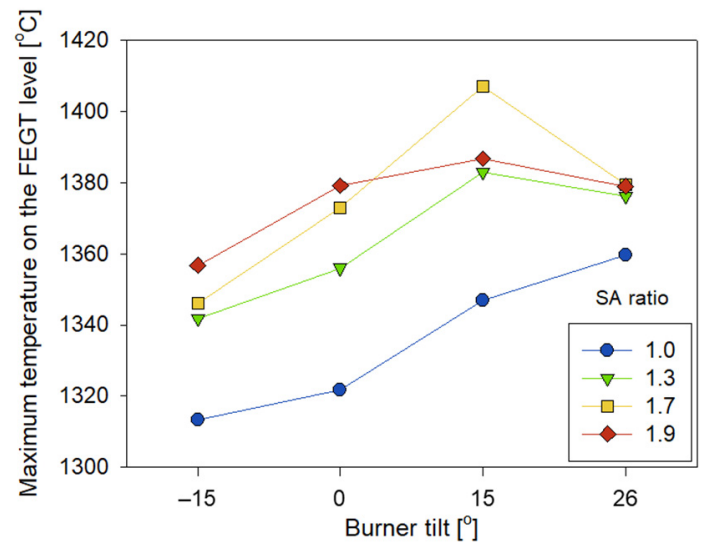

Figure 8. Peak temperature of the furnace exit gas temperature (FEGT) level for all simulation cases.

Despite the non-uniformity in the flow and temperature caused by the uneven SA supply, the steam temperature sent to the turbine did not have a major disruption during 
the actual operation. This was because the four sections of each heat exchanger were connected to the next heat changer, alternating left/right and inner/outer, as illustrated in Figure 2. Such an arrangement was crucial in alleviating the differences in the heat transfer caused by the large deviations in the local flow and temperature distribution.

\subsection{Parametric Study: Influence on Wall Heat Flux}

Figure 9 compares the contours of the heat flux on the four walls of the burner zone for the selected cases. Case $\mathrm{C} 1.0+0^{\circ}$ had a very similar pattern of heat flux between the four walls, with a peak value of $213.4 \mathrm{~kW} / \mathrm{m}^{2}$. In contrast, the cases with an SA ratio of 1.7 exhibited a larger heat flux on the front and right walls influenced by the clockwise rotation of the stronger jets from corners \#1 and \#2. In particular, the right wall exhibited the largest heat absorption, with a peak heat flux of over $230 \mathrm{~kW} / \mathrm{m}^{2}$. As the burners turned upward, the heat flux decreased in the lower part of the burner zone and at the bottom cone. This reduced the total heat absorption in the evaporator.

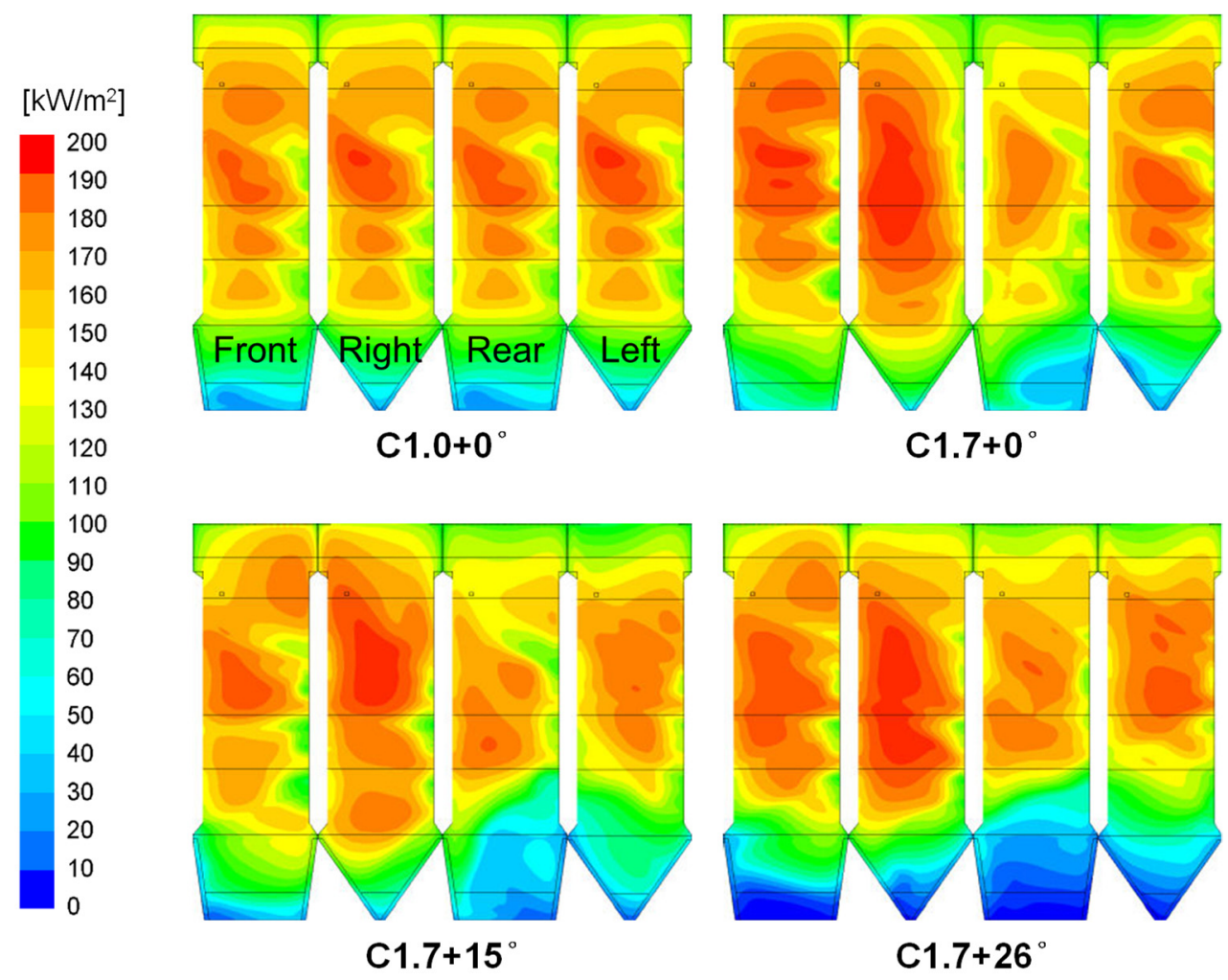

Figure 9. Predicted heat flux on the walls in the burner zone for selected cases.

For quantitative analysis of the heat transfer characteristics, two representative parameters were evaluated: the heat absorption ratio and total wall heat absorption, as shown in Figure 10. The heat absorption ratio was defined as the sum of the heat absorption on the front and right walls divided by that on the rear and left walls. As the SA ratio increased, the heat absorption became more uneven between the walls with a peak heat absorption ratio of 1.19 for case $\mathrm{C} 1.7+15^{\circ}$; however, the magnitude was much smaller than the SA ratio. The differences in heat absorption between the walls were alleviated by negative burner angles. 


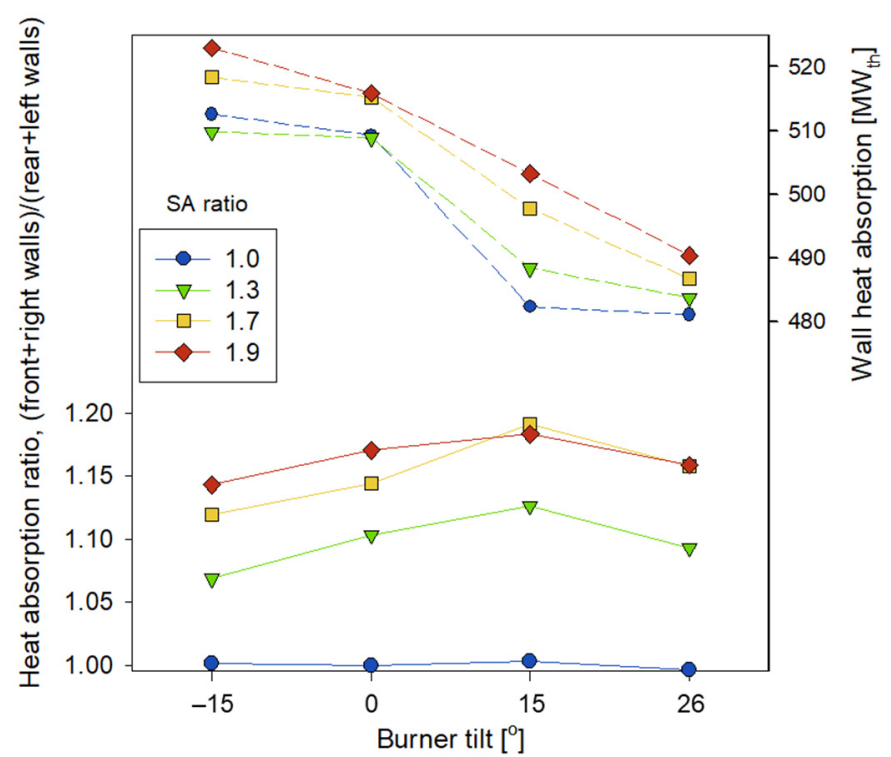

Figure 10. Heat absorption ratio (between front + right walls and rear + left walls) and total wall heat absorption for different $\mathrm{SA}$ ratios and burner tilt angles.

Figure 10 also shows the total wall heat absorption. The upward burner tilt is known to decrease the wall heat absorption $[7,9,38]$, and the ability to control the wall heat absorption using the burner tilt is an advantage of the TF boiler. Under normal operation with an SA ratio of 1, the wall heat absorption decreased from $512 \mathrm{MW}_{\text {th }}$ to $481 \mathrm{MW}_{\text {th }}$ as the burner turned upward from $-15^{\circ}$ to $26^{\circ}$. The same trend was observed for uneven SA ratios. Meanwhile, a larger SA ratio increased the total wall heat absorption because the stronger jets pushed the hot gas flow closer to the walls. On average, the wall heat absorption with an SA ratio of 1.3, 1.7, and 1.9 was 1.4 $\mathrm{MW}_{\mathrm{th}}, 8.2 \mathrm{MW}_{\mathrm{th}}$, and $11.8 \mathrm{MW}_{\text {th }}$ larger, respectively, than that of normal operation. These values corresponded to $0.11 \%, 0.66 \%$, and $0.94 \%$ of the thermal input, respectively. When the opposite influence of the SA ratio and burner tilt on the wall heat absorption is considered, the burner tilt was required to be higher during operations with an uneven SA supply to maintain the heat distribution between the evaporator and convective sections, similar to the normal operation. As regards the magnitude of non-uniformity and peak temperature on the FEGT level discussed in Section 3.3, a high burner tilt of $+26^{\circ}$ was preferred, whereas $+15^{\circ}$ was the least favorable.

\subsection{Parametric Study: Influence on Chemical Reactions and NOx Emission}

Figure 11 compares the predicted $\mathrm{O}_{2}$ contours for the selected cases. Case $\mathrm{C} 1.0+0^{\circ}$ had an axisymmetric distribution with higher $\mathrm{O}_{2}$ concentrations appearing along the trajectories of the air jets on the burner levels. Because the burner zone (excluding CCOFA) was fuel-rich with a stoichiometric ratio of $0.97, \mathrm{O}_{2}$ outside the air jets was almost depleted. The CCOFA at the top of the burner zone supplied the excess air that proceeded along the walls through the rotating flow and gradually mixed with the combustion gas. When the SA supply was uneven in the $\mathrm{C} 1.7$ cases, the non-uniformity of the $\mathrm{O}_{2}$ concentration was significant at the platen $\mathrm{SH}$ level after the supply of CCOFA, in which $\mathrm{O}_{2}$ was rich mainly near the right wall. The location of the $\mathrm{O}_{2}$-rich region was different from that of the high-temperature region on the platen SH level in Figure 5, which shows non-uniformity in the reaction stoichiometry. The $\mathrm{O}_{2}$ pattern at the boiler exit in the subsets of Figure 11 was reversed front to rear from that of the platen $\mathrm{SH}$ level because the flow turned downward in the second pass. The larger SA flow rate on the left windbox resulted in a higher $\mathrm{O}_{2}$ concentration on the right half at the boiler exit. This is consistent with the trend of the actual operation cases. 


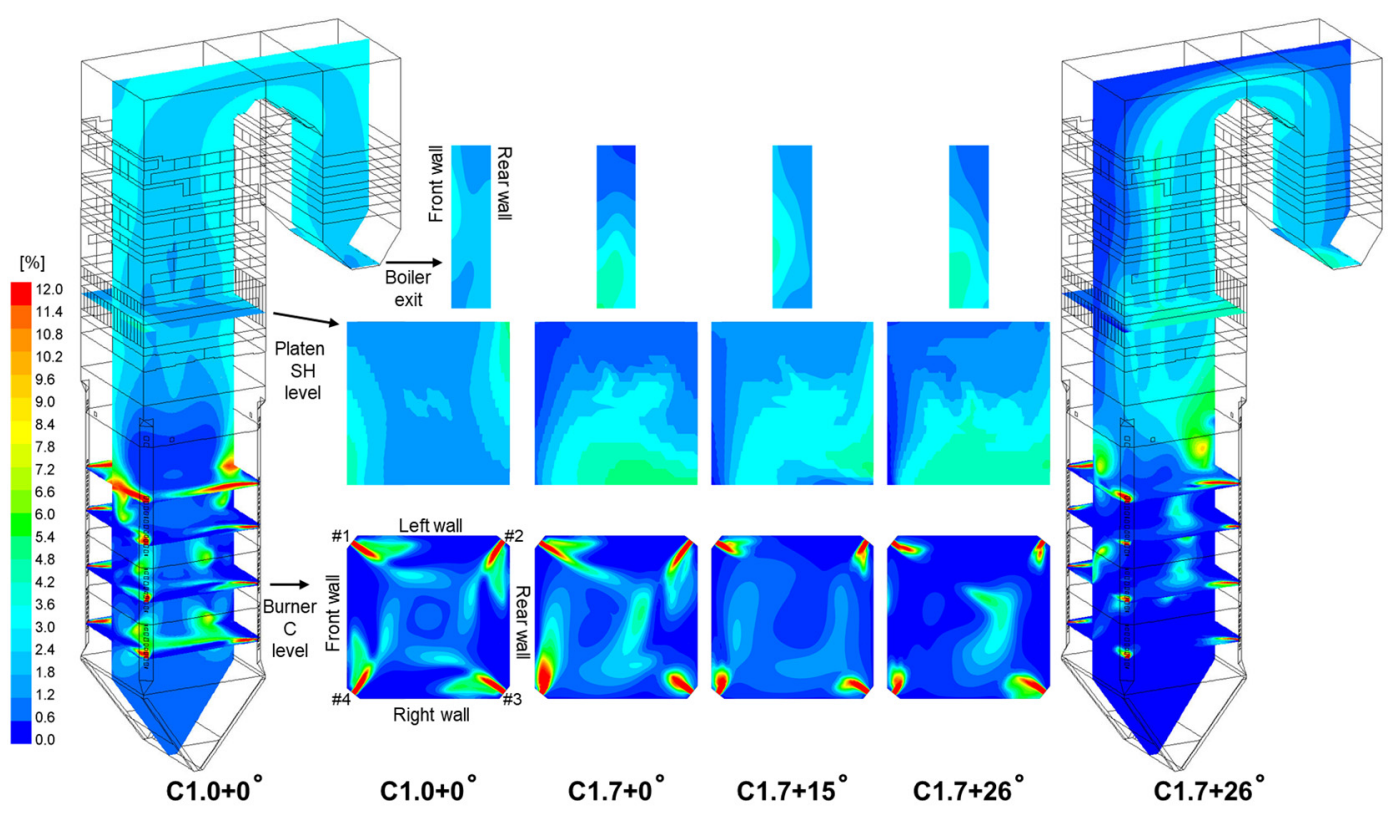

Figure 11. Predicted $\mathrm{O}_{2}$ contours for selected cases.

Figure 12 shows the predicted total carbon conversion calculated from the difference between the carbon input from coal and residual carbon concentration at the boiler exit. Despite the non-uniformity in the reaction stoichiometry, the influence of uneven SA supply was small and mixed. In contrast, the influence of burner tilt was significant regardless of the SA ratio. The upward burner tilt decreased the carbon conversion both in the bottom and fly ashes. It pushed the coal and air upward, shortening the retention time before the gas was quenched by the heat exchanger. Meanwhile, the coal particles entrained to a down flow into the bottom hopper experienced a lower $\mathrm{O}_{2}$ concentration and a weaker momentum to drag the particles back into the burner zone above. Generally, the total carbon conversion was over $99.4 \%$ which was satisfactorily high despite small $(<0.1 \%)$ differences between cases. This was consistent with the actual operation in cases A1-A6 where unburned carbon was not an issue.

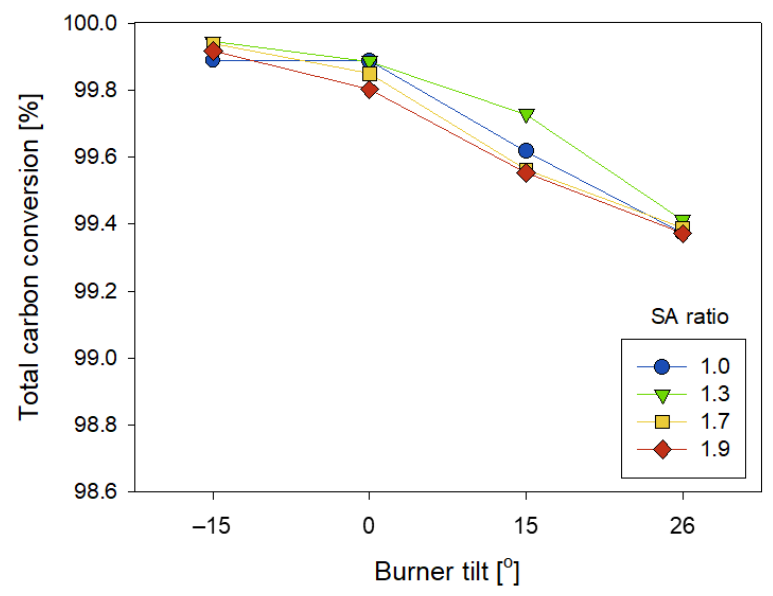

Figure 12. Predicted total carbon conversion for different SA ratios and burner tilt angles.

Figure 13 shows the contours of the NOx concentration on the center plane of the furnace and the profiles of mass-weighted average values on horizontal cross-sections for selected cases. In Figure 13a, the regions with NO concentrations higher than 400 ppm were caused by fuel NO formation. Outside these regions, the NO concentration decreased owing to reduction reactions (mainly by char and partially by thermal NOx mechanism) and dilution owing to fresh air supply, such as CCOFA. The contours of the three C1.7 
cases showed the impact of an imbalance in the reaction stoichiometry. The NO formation was concentrated close to the right wall, where more air and coal particles were present to release fuel NO, whereas the $\mathrm{NO}$ concentration decreased in the central region. Compared to case $\mathrm{C} 1.7+0^{\circ}$, the burner tilt in case $\mathrm{C} 1.7+15^{\circ}$ shifted the high-NO regions upward while decreasing the NO concentration in the bottom cone. The NO concentration near the right wall of the upper furnace was the highest at a tilt angle of $+26^{\circ}$. Such trends can also be observed in Figure 13b for the average NO concentrations. Once all the coal was supplied in the burner zone, a sharp peak of $\mathrm{NO}$ concentration appeared between the burner $\mathrm{F}$ level and CCOFA $(\mathrm{z}=22.4 \mathrm{~m})$ for cases $\mathrm{C} 1.0+0^{\circ}$ and $\mathrm{C} 1.7+0^{\circ}$. From there and above, the NO concentration decreased rapidly owing to reduction reactions and dilution by CCOFA. The peak was delayed by $1.0 \mathrm{~m}$ in case $\mathrm{C} 1.7+15^{\circ}$ by the burner tilt and the decrease in the NO concentration became mild. In case $\mathrm{C} 1.7+26^{\circ}$, no peak was observed between burner $\mathrm{F}$ level and CCOFA, whereas the NO concentration was the lowest. This was because the carbon conversion and corresponding fuel $\mathrm{NO}$ release were significantly delayed by the highest burner tilt. The NO concentration even increased above the CCOFA and became close to the level of case $\mathrm{C} 1.7+15^{\circ}$.
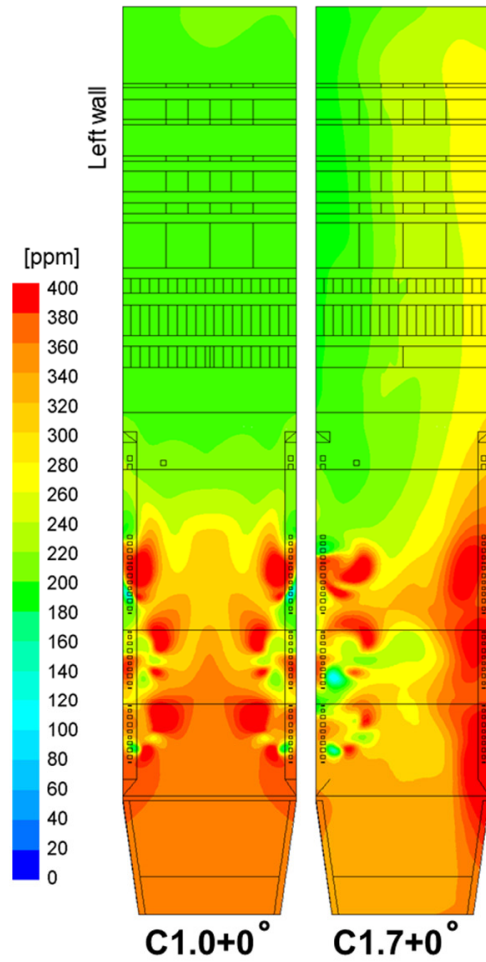

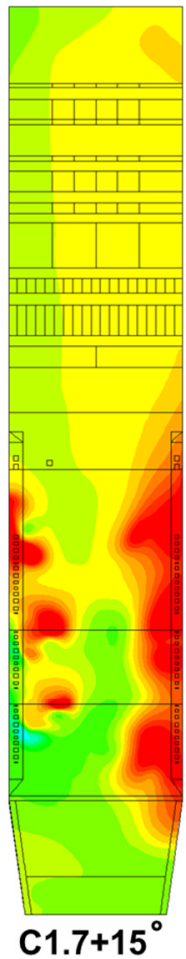

(a)

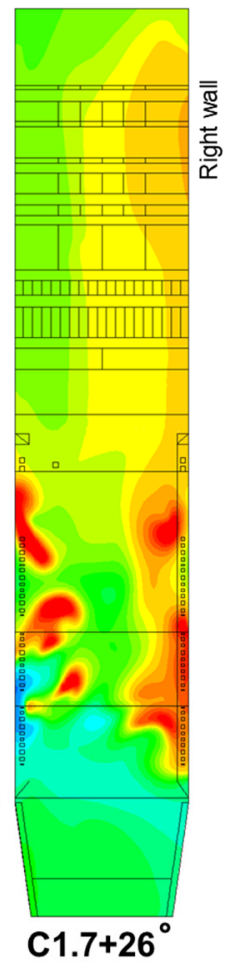

$\mathbf{C} 1.7+26^{\circ}$

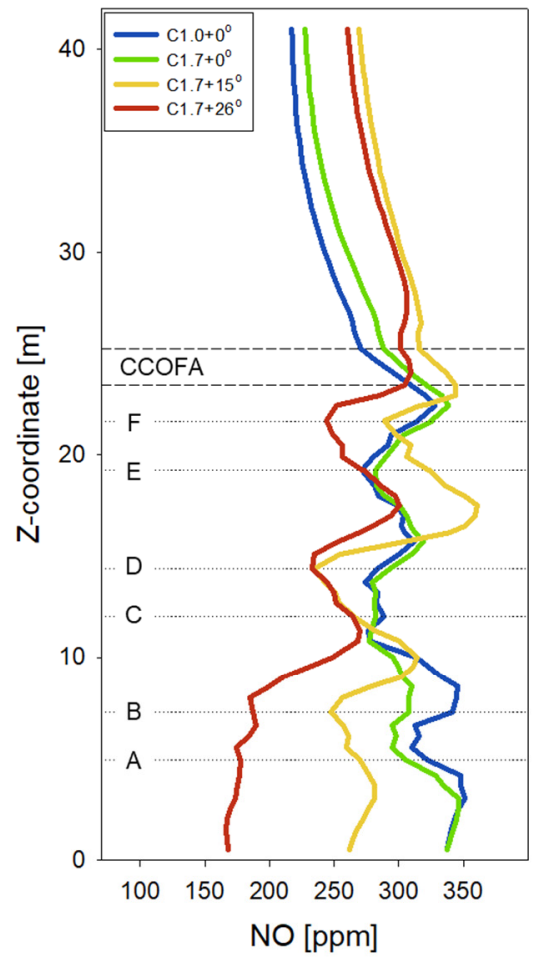

(b)

Figure 13. Predicted NO concentrations for selected cases: (a) contours on the center plane and (b) profiles of massweighted average.

Figure 14 shows the $\mathrm{NO}$ emission (corrected to $6 \% \mathrm{O}_{2}$ ) at the economizer exit for all cases. The uneven SA flow distribution increased the NO emission by 8-21 ppm, which was on average $6.7 \%$ larger than the respective normal operation cases. However, the differences between the cases of uneven SA supply were not large. Conversely, the NO emission increased at positive burner angles, as compared with $0^{\circ}$ or negative angles. This was consistent with the findings in the literature $[7,9,38]$. The relatively slight influences of the SA ratio and burner tilt suggest that the very low NOx emissions observed for cases A5 and A6 in Table 4 were mainly because of the low thermal input (approximately $70 \%$ load, as shown in Table 1). 


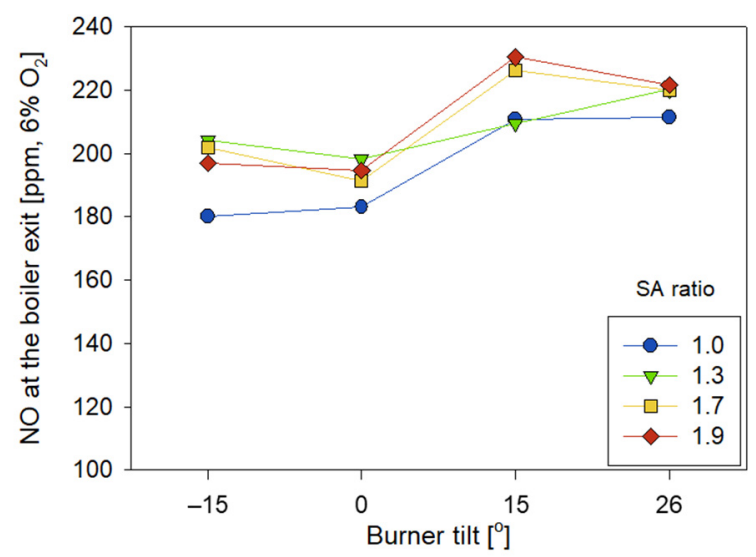

Figure 14. Predicted NO emissions at the boiler exit for different SA ratios and burner tilt angles.

\section{Conclusions}

This study investigated the flow and reaction characteristics of a 500 MWe tangentialfiring coal boiler during uneven SA supply between two windboxes and the influence of burner tilt. Using the CFD model validated for six cases of actual operation, a parametric study was performed for 16 cases with varying SA ratios up to 1.9 , and burner tilt between $-15^{\circ}$ and $26^{\circ}$. The uneven SA supply deformed the fireball and caused severe disruptions in the uniformity of local flow pattern, temperature, and reaction stoichiometry, which was unfavorable for various aspects of boiler performance. The main findings are as follows.

- The characteristic axisymmetric flow pattern of the TF boiler formed by the jets from the corners was distorted by the uneven SA supply. The SA ratio of 1.3 induced approximately $20 \%$ and $4 \%$ deviations from axisymmetry in the flow and temperature, respectively. The deviations increased to approximately $30 \%$ and $6 \%$, respectively, for an $S A$ ratio of 1.7 .

- With stronger SA jets from the left windbox pushing the fireball closer to the front and right walls, the heat flux on the two walls was concentrated by up to $19 \%$ more than that on the other walls. This also increased the heat absorption on the wall (evaporator) by up to $20.9 \mathrm{MW}_{\text {th }}(0.94 \%$ of the thermal input), lowering the heat absorption in the convective heat exchangers correspondingly.

- Despite the larger heat transfer to the walls, the peak gas temperature on the FEGT level also increased by as much as $60{ }^{\circ} \mathrm{C}$ because of the large temperature deviations which may lead to severe ash slagging.

- The disruption in the local reaction stoichiometry increased the NOx emissions by $6.7 \%$ on average. The air-rich pockets had increased fuel NO formation, whereas the fuel-rich pockets had delayed char conversion, leading to a late release of NO.

- In alleviating the impact of the uneven SA supply on the uniformity of flow pattern, temperature, and heat transfer, the high burner tilt of $+26^{\circ}$ was helpful whereas $+15^{\circ}$ was found to be the least favorable.

- Even with the uneven SA supply, the burner tilt provided a consistent influence on the boiler performance including the heat distribution between heat exchangers, the carbon conversion, and NOx emission. This implies that the burner tilt can be controlled to $0^{\circ}$ or lower if the NOx emission needs to be reduced.

Further studies are required on the control strategy during the uneven SA supply including the degree of air staging and yawing which are other main parameters for boiler operation. 
Supplementary Materials: The following are available online at https:/ / www.mdpi.com/article/10 .3390 / en14248352/s1, Figure S1: Mesh constructed for the boiler $(4,445,838$ hexahedral and 311,638 tetrahedral cells), Table S1: Detailed operating conditions for cases with uneven air supply between corners, Table S2: Fuel properties of coal blend for each case, Table S3: Composition and release kinetics of devolatilization products based on prediction of FLASHCHAIN.

Author Contributions: Conceptualization, H.J.; Methodology, Investigation, Writing-original draft. J.P.; Validation, Formal analysis, W.K.; Software, Visualization. J.H.; Resources, Conceptualization, S.Y.; Resources, Data curation, H.R.; Resources, Data curation, C.R.; Funding acquisition, Project administration, Writing-review and editing. All authors have read and agreed to the published version of the manuscript.

Funding: This work was supported by the National Research Council of Science \& Technology (NST) grant by the Korea government (MSIT) (No. CRC-20-02-KIST).

Acknowledgments: The authors would like to thank Korea Western Power Co., Ltd. for their help and support.

Conflicts of Interest: The authors declare no conflict of interest.

\section{Nomenclature}

Symbols

$\begin{array}{ll}\text { A } & \text { Pre-exponential factor }\left[\mathrm{s}^{-1}\right], \\ \text { B } & \text { Magnussen constant } \\ d & \text { Magnussen constant } \\ E & \text { Diameter }[\mathrm{cm}] \\ G & \text { Activation energy }[\mathrm{kJ} / \mathrm{kmol}] \\ K_{e q} & \text { Mass velocity }\left[\mathrm{kg} / \mathrm{m}^{2} \cdot \mathrm{s}\right] \\ k & \text { Chemical equilibrium constant } \\ P & \text { Reaction rate }\left[\mathrm{g} \cdot \mathrm{cm}^{-2} \cdot \mathrm{atm}^{-1} \cdot \mathrm{s}^{-1}\right] \\ R & \text { Turbulent kinetic energy }\left[\mathrm{m}^{2} \cdot \mathrm{s}^{-2}\right] \\ R & \text { Pressure [atm] } \\ T & \text { Universal gas constant, } \\ V & \text { Reaction rate of char }\left[\mathrm{g} \cdot \mathrm{cm}^{-2} \cdot \mathrm{s}^{-1}\right] \\ Y & \text { Temperature }[\mathrm{K}] \\ M & \text { Volatile matter }[\mathrm{kg}] \\ & \text { Char core to particle diameter ratio, } \\ & \text { Mass fraction } \\ & \text { Molecular weight }\end{array}$

Greek Symbols

$\varepsilon$

Porosity of the ash layer,

Turbulent dissipation

$\rho \quad$ Density $\left[\mathrm{kg} / \mathrm{m}^{3}\right]$

$v \quad$ Stoichiometric coefficient

\begin{tabular}{ll}
\multicolumn{2}{l}{ Subscripts } \\
char & Unreacted char core \\
diff & Diffusion rate \\
dash & Diffusion rate in the ash-layer \\
$i$ & Index of gasification reaction \\
$o$ & Initial \\
$p$ & Particle \\
$t$ & Total pressure \\
$\mathrm{R}$ & Reactant \\
$\mathrm{P}$ & Product
\end{tabular}

Subscripts

char Unreacted char core

diff Diffusion rate

dash Diffusion rate in the ash-layer

Index of gasification reaction

Initial

Particle

Total pressure

P Product

\section{References}

1. Bozzuto, C. Clean Combustion Technologies: A Reference Book on Steam Generation and Emissions Control, 5th ed.; ALSTOM: Windsor, CT, USA, 2009.

2. Laubscher, R.; Rousseau, P. Numerical investigation on the impact of variable particle radiation properties on the heat transfer in high ash pulverized coal boiler through co-simulation. Energy 2020, 195, 117006. [CrossRef]

3. Sorrentino, G.; Ceriello, G.; De Joannon, M.; Sabia, P.; Ragucci, R.; Van Oijen, J.; Cavaliere, A.; De Goey, L.P.H. Numerical investigation of moderate or intense low-oxygen dilution combustion in a cyclonic burner using a flamelet-generated manifold approach. Energy Fuels 2018, 32, 10242-10255. [CrossRef]

4. Johansson, R.; Andersson, K.; Leckner, B.; Thunman, H. Models for gaseous radiative heat transfer applied to oxy-fuel conditions in boilers. Int. J. Heat Mass Transf. 2010, 53, 220-230. [CrossRef]

5. Yin, C.; Johansen, L.C.R.; Rosendahl, L.A.; Kær, S.K. New weighted sum of gray gases model applicable to computational fluid dynamics (CFD) modeling of oxy-fuel combustion: Derivation, validation, and implementation. Energy Fuels 2010, 24, 6275-6282. [CrossRef]

6. Yin, C. On gas and particle radiation in pulverized fuel combustion furnaces. Appl. Energy 2015, 157, 554-561. [CrossRef]

7. Tan, P.; Tian, D.; Fang, Q.; Ma, L.; Zhang, C.; Chen, G.; Zhong, L.; Zhang, H. Effects of burner tilt angle on the combustion and NOx emission characteristics of a 700 MWe deep-air-staged tangentially pulverized-coal-fired boiler. Fuel 2017, 196, 314-324. [CrossRef]

8. Yu, C.; Xiong, W.; Ma, H.; Zhou, J.; Si, F.; Jiang, X.; Fang, X. Numerical investigation of combustion optimization in a tangential firing boiler considering steam tube overheating. Appl. Therm. Eng. 2019, 154, 87-101. [CrossRef] 
9. Chang, J.; Wang, X.; Zhou, Z.; Chen, H.; Niu, Y. CFD modeling of hydrodynamics, combustion and NOx emission in a tangentially fired pulverized-coal boiler at low load operating conditions. Adv. Powder. Technol. 2021, 32, 290-303. [CrossRef]

10. Tian, D.; Zhong, L.; Tan, P.; Ma, L.; Fang, Q.; Zhang, C.; Zhang, D.; Chen, G. Influence of vertical burner tilt angle on the gas temperature deviation in a $700 \mathrm{MW}$ low NOx tangentially fired pulverized-coal boiler. Fuel Process. Technol. 2015, 138, 616-628. [CrossRef]

11. Park, H.Y.; Baek, S.H.; Kim, Y.J.; Kim, T.H.; Kang, D.S.; Kim, D.W. Numerical and experimental investigations on the gas temperature deviation in a large scale, advanced low NOx, tangentially fired pulverized coal boiler. Fuel 2013, 104, 641-646. [CrossRef]

12. Yao, Z.; Liu, J.; Qiu, Z.; Pan, W.; Wu, Z. Numerical investigation of $700{ }^{\circ} \mathrm{C}$ boiler flue gas thermal deviation based on orthogonal experiment. Fuel 2021, 295, 120510. [CrossRef]

13. Wu, X.; Fan, W.; Liu, Y.; Bian, B. Numerical simulation research on the unique thermal deviation in a $1000 \mathrm{MW}$ tower type boiler. Energy 2019, 173, 1006-1020. [CrossRef]

14. Xu, L.; Huang, Y.; Zou, L.; Yue, J.; Wang, J.; Liu, C.; Liu, L.; Dong, L. Experimental research of mitigation strategy for hightemperature corrosion of waterwall fireside in a $630 \mathrm{MWe}$ tangentially fired utility boiler based on combustion adjustments. Fuel Process. Technol. 2019, 188, 1-15. [CrossRef]

15. Jo, H.; Kang, K.; Park, J.; Ryu, C.; Ahn, H.; Go, Y. Optimization of air distribution to reduce NOx emission and unburned carbon for the retrofit of a $500 \mathrm{MWe}$ tangential-firing coal boiler. Energies 2019, 12, 3281. [CrossRef]

16. Jiang, Y.; Ahn, S.; Oh, D.H.; Lee, B.H.; Jeon, C.H. Optimization of separated overfire air to reduce NOx emissions under combustion stability for the retrofit of a $500 \mathrm{MW}$ tangentially pulverized coal boiler. Fuel 2021, 289, 119764. [CrossRef]

17. Liu, X.; Zhang, J.; Tan, H.; Mo, Q.; Wang, X.; Wang, Y. Numerical and experimental study on co-firing of low volatile coal in a 330 MW tangentially fired boiler. J. Energy Inst. 2021, 96, 242-250. [CrossRef]

18. Jiang, Y.; Park, K.H.; Jeon, C.H. Feasibility study of co-firing of torrefied empty fruit bunch and coal through boiler simulation. Energies 2020, 13, 3051. [CrossRef]

19. Wang, P.; Wang, C.; Du, Y.; Feng, Q.; Wang, Z.; Yao, W.; Liu, J.; Zhang, J.; Che, D. Experiments and simulation on co-combustion of semicoke and coal in a full-scale tangentially fired utility boiler. Energy Fuels 2019, 33, 3012-3027. [CrossRef]

20. Tan, P.; Fang, Q.; Zhao, S.; Yin, C.; Zhang, C.; Zhao, H.; Chen, G. Causes and mitigation of gas temperature deviation in tangentially fired tower-type boilers. Appl. Therm. Eng. 2018, 139, 135-143. [CrossRef]

21. Zhao, S.; Fang, Q.; Yin, C.; Wei, T.; Wang, H.; Zhang, C.; Chen, G. New fuel air control strategy for reducing NOx emissions from corner-fired utility boilers at medium-low loads. Energy Fuels 2017, 31, 6689-6699. [CrossRef]

22. Jo, H.; Kang, K.; Park, J.; Ryu, C.; Ahn, H.; Go, Y. Detailed assessment of mesh sensitivity for CFD simulation of coal combustion in a tangential-firing boiler. J. Mech. Sci. Technol. 2020, 34, 917-930. [CrossRef]

23. ANSYS Inc. ANSYS Fluent User Guide; ANSYS Inc.: Cannonsburg, PA, USA, 2016.

24. Shih, T.H.; Liou, W.W.; Shabbir, A.; Yang, Z.; Zhu, J. A new k- $\varepsilon$ eddy-viscosity model for high Reynolds number turbulent flows-model development and validation. Comput. Fluids 1995, 24, 227-238. [CrossRef]

25. Chui, E.H.; Raithby, G.D. Computation of radiant heat transfer on a nonorthogonal mesh using the finite-volume method. Numer. Heat Transf. Part B 1993, 23, 269-288. [CrossRef]

26. Fordoei, E.E.; Mazaheri, K. Numerical study of chemical kinetics and radiation heat transfer characteristics on the temperature distribution in the oxy-fuel combustion. Heat Mass Transf. 2019, 55, 2025-2036. [CrossRef]

27. Krishnamoorthy, G. A computationally efficient P1 radiation model for modern combustion systems utilizing pre-conditioned conjugate gradient methods. Appl. Therm. Eng. 2017, 119, 197-206. [CrossRef]

28. Smith, T.F.; Shen, Z.F.; Friedman, J.N. Evaluation of coefficients for the weighted sum of gray gases model. J. Heat Transfer 1982, 104, 602-608. [CrossRef]

29. Niksa, S. PC Coal Lab Version 4.1: User Guide and Tutorial; Niksa Energy Associates LLC: Belmont, CA, USA, 1997.

30. Wen, C.Y.; Chaung, T.Z. Entrainment coal Gasification Modeling, Industrial and engineering chemistry process design and development. Ind. Eng. Chem. Process Des. Dev. 1979, 10, 684-695. [CrossRef]

31. Jones, W.P.; Lindstedt, R.P. Global reaction schemes for hydrocarbon combustion. Combust. Flame 1988, 73, 233-249. [CrossRef]

32. Smoot, L.D.; Smith, P.J. Coal Combustion and Gasification; Plenum Press: New York, NY, USA, 1985.

33. Magnussen, B.F.; Hjertager, B.H. On mathematical models of turbulent combustion with special emphasis on soot formation and combustion. Proc. Combust. Inst. 1977, 16, 719-729. [CrossRef]

34. Hanson, R.K.; Salimian, S. Survey of Rate Constants in H/N/O Systems. In Combustion Chemistry; Gardiner, W.C., Ed.; Springer: New York, NY, USA, 1984; pp. 361-421.

35. De Soete, G.G. Overall reaction rates of NO and N2 formation from fuel nitrogen. Proc. Combust. Inst. 1975, 15, 1093-1102. [CrossRef]

36. Park, H.Y.; Lee, J.E.; Kim, H.H.; Park, S.; Beak, S.H.; Ye, I.; Ryu, C. Thermal resistance by slagging and its relationship with ash properties for six coal blends in a commercial coal-fired boiler. Fuel 2019, 235, 1377-1386. [CrossRef]

37. Park, J.K.; Park, S.; Kim, M.K.; Ryu, C.; Baek, S.H.; Kim, Y.J.; Kim, H.H.; Park, H.Y. CFD analysis of combustion characteristics for fuel switching to bioliquid in oil-fired power plant. Fuel 2015, 159, 324-333. [CrossRef]

38. Jameel, A.G.A.; Dahiphale, C.; Alquaity, A.B.; Zahid, U.; Jayanti, S. Numerical simulation of coal combustion in a tangential pulverized boiler: Effect of burner vertical tilt angle. Arabian J. Sci. Eng. 2021. [CrossRef] 